Gildas and Arthur

Author(s): A. O. Anderson

Source: The Celtic Review, Vol. 8, No. 30 (Oct., 1912), pp. 149-165

Published by:

Stable URL: http://www.jstor.org/stable/30070428

Accessed: 13-11-2015 20:47 UTC

Your use of the JSTOR archive indicates your acceptance of the Terms \& Conditions of Use, available at http://www.jstor.org/page/ info/about/policies/terms.jsp

JSTOR is a not-for-profit service that helps scholars, researchers, and students discover, use, and build upon a wide range of content in a trusted digital archive. We use information technology and tools to increase productivity and facilitate new forms of scholarship. For more information about JSTOR, please contact support@jstor.org. 
In my bonnie native glen, In my bonnie native glen, $\mathrm{O}$ ! 'twere dear delight tae wander In my bonnie native glen.

At the early peep o' mornin', When the grass was wat wi' dew, Amang the woods o' hazel Gaily sang the shy cuckoo; $A n^{\prime}$ the calves clean daft wi' joy Gaed a' friskin' roun' the pen; Now we 've nae sic scenes o' gladness In my bonnie native glen.'

I saw a copy of Alexander Macdonald's poetry that did duty at the mines of Ballarat and Johannesburg. An old lady in the sub-tropics of Australia rehearsed in my hearing verse after verse of Dugald Buchanan's poems, transporting herself in the very act to the happy days of childhood, round the peat fire in far-away Lochabar. These songs have been sung by the shepherds on the lonely moors, and by the fishermen on the rolling deep. From lip to lip they have been wafted across hill and dale from one generation to another. The intensity of their feeling has fired the spirit of many a forlorn Gael. This literature deserves to be studied. No student of the language can speak with authority who has not dipped deeply into this treasure; and the future historian who will portray Highland life or character in its many vicissitudes, in its depression and in its joy, will fail to do so accurately unless he studies diligently the literature of the Scottish Gael.

\section{GILDAS AND ARTHUR}

\section{A. O. Anderson 1}

The date given by Gildas for the battle of Badon is the only contemporary evidence we have of the time of Arthur's reign: this battle is named in the Historia Brittonum

1 This paper has been written during tenure of a Carnegie Research Fellowship. 
(written a century and a half or three centuries later) as the twelfth of Arthur's victories.

These are Gildas's words (De Excidio Britanniae, chs. xxv.-xxvi. ; Mommsen's edition, p. 40) :-

' Tempore igitur interveniente aliquanto, cum recessissent domum crudelissimi praedones, ... reliquiae . . miserrimi cives, . . . duce Ambrosio Aureliano,... (cujus nunc temporibus nostris suboles magnopere avita bonitate degeneravit), vires capessunt, victores provocantes ad praelium: quis victoria domino annuente cessit.

[26. De postrema patriae victoria quae temporibus nostris dei nutu donata est.]

' Ex eo tempore nunc cives, nunc hostes, vincebant, . . . usque ad annum obsessionis Badonici montis, novissimaeque ferme de furciferis non minimae stragis, quique quadragesimus quartus ut novi orditur (v.l. oritur) annus, mense jam uno emenso, qui et meae nativitatis est. Sed ne nunc quidem, ut antea, civitates patriae inhabitantur. . . .

Bede seems to have understood this passage to mean that the battle was fought 'about the 44th year from the arrival of [the Saxons] in Britain' (Historia Ecclesiastica, i. 16). The Rev. C. Plummer (Bede, ii. 31) suggests that this might have been a different computation, rather than a misunderstanding of Gildas's text; it would be possible for both computations to have been correct. But Bede is certainly quoting from Gildas. The version which Bede used may have been glossed or altered. ${ }^{1}$

It has been generally accepted that in this passage Gildas says he was born in the year of the battle of Badon, and wrote in the forty-fourth year afterwards. The Rev. C. Plummer says: "The present tense, "oritur," shows that Gildas refers to the time at which he was writing, and he says that it was " at the end of the first month of the fortyfourth year [from the year of that event], which is also

1 Bede's words are: '. . . victoriam ipsi, Deo favente, suscipiunt. Et ex eo tempore nunc cives nunc hostes vincebant, usque ad annum obsessionis Badonici montis, quando non minimas eisdem hostibus strages dabant, XLmo circiter et IIIIo anno adventus eorum in Brittaniam.' 
the year of my birth." (So I would construe the passage.)'

Mommsen (Auctores, xiii. 8) would correct the passage thus: the words ut novi have no sense; and the year which orditur mense jam uno emenso can only have been the year in which Gildas wrote ; therefore a possible emendation would be quique quadragesimus quartus [est ab eo qui] orditur annus. "Thus Gildas says that he is writing in the forty-fourth year from the siege of Mount Badon, and also from the time of his birth '; reckoning from the last British victory, as it is called in the rubric.

It is hazardous to oppose the views of so great scholars. But I venture to suggest that ut novi (" as I happen to know') is not certainly out of place here; and that mense jam uno emenso does not necessarily imply that the year is spoken of as present, any more than does the present tense orditur. The contrary would appear from the succeeding clause, qui et meae nativitatis est, 'this too is the [year ?] of my birth.' He certainly did not write in the year of his birth. I suggest that this part of the sentence is constructed in the historical present tense. As may be seen in the previous sentence, Gildas's style does not preclude mixture of tenses. In the next sentence, however, he does speak of the year in which he writes.

If the passage is corrupt, a satisfactory emendation must supply (before, or in place of, ut novi) words which would indicate the point of time in the past from which the reckoning was made. The words 'one month already having passed' do not fit in with Mommsen's suggested reading, which counts backwards from the present. Possibly we might read ut novi [dicunt], ' according to the new style.' Gildas might have meant that the year was numbered 44 in some paschal calendar, but unless he had a Victorian cycle beginning with A.D. 457 (the date of its publication) no other era fits ; and this was not the usual year of commencement. No era had been universally adopted to date by in those days, so that when an era was counted from it 
had to be specified. To indicate an era we should have to make unjustifiable changes in the text.

Sense can be made of the passage as it stands, after this fashion: 'After a considerable interval of time, when the most cruel robbers [the Saxons] had returned home, ... the remnants [of the Britons] ... (most wretched citizens) collected their strength, and challenged the victors to battle, ... . led by Ambrosius Aurelianus, ... . (whose descendants have greatly fallen off, now in our times, from the excellence of their ancestors); and, through God's favour, victory fell to [the Britons].

'Of our country's last victory, which by God's favour was granted in our times.

'From that time sometimes the citizens, sometimes the enemy, were victorious ; . . . down to the year in which the mountain of Badon was besieged, and almost the last considerable slaughter [was made] of the miscreants, and which was, as I [happen to] know, the beginning of the forty-fourth year; one month already having passed, which was also the [month ?] of my birth. But not even yet are our country's cities inhabited as before.'

The rubric implies (temporibus nostris) that the battle was fought in Gildas's lifetime. It would be natural to understand that Gildas dated his birth forty-three years after some event, and the battle of Badon in the month after his birth.

We look, therefore, for some event mentioned, from which Gildas may have counted. The only words here which indicate such an event are the first words of the sentence, ex eo tempore; that is, from the time of the success of Ambrose over the invaders. ${ }^{1}$

Octha and Ebissa are said in the Historia Brittonum (ch. xxxviii.) to have led a settlement into the country between the Solway and the northern wall, in the beginnings of Saxon occupation of Britain. The Historia Brittonum

1 Since writing the above, I find that Mr. E. W. B. Nicholson has suggested the same interpretation in this Review, ii. 374, 378. 
places Arthur's victories indefinitely after the retiral of Octha from the south-west of Scotland to Kent. This retiral (if it occurred) may have been the occasion of Ambrose's success, which took place, according to Gildas, ' after the most cruel robbers had returned home.'

Geoffrey of Monmouth (who writes six centuries later than Gildas) places Ambrose's great victory at Kaerconan; Hengist, he says, was killed, the Saxons fled in all directions, to cities, to mountains, and to ships; 'but Octa, Hengist's son, went to York with the greater number; and his kinsman Eosa [went to] the town of Dumbarton, and fortified himself there with innumerable armed men.' Of course Geoffrey has no authority, but there may have been a germ of truth in the tradition which underlies this account.

Chapter sixty-six added to the Historia Brittonum implies that Ambrose flourished in [437]. The Historia Brittonum (ch. xxxi.) says that Vortigern was alarmed by the extent of Ambrose's power. Chapter forty-eight of the same work (derived from the Liber S. Germani) says that Ambrose became the next over-king of Britain, and that he gave to Vortigern's heir part of Vortigern's kingdom, Buelt and Guorthigirniaun. Ambrose's success probably took place several years after Vortigern's death; and Vortigern died late in 447 or early in 448. From the time of Ambrose's victory to the time when Gildas wrote, the Saxons had occupied no more of the Britons' lands.

It would have been entirely natural for Gildas's parents to have kept count of the years from the success of Ambrose, an event which saved their part of Britain from slavery.

Bede places the battle of Badon somewhere about 493 . Zimmer thinks that Gildas cannot have been born much later than 496. Zimmer's argument rests upon the early date at which Gildas acquired authority. But possibly royal birth might have given Gildas authority beyond his years; and it might well be argued that the epistle was the work of a man still young : its audacity suggests rather 
youthful ardour than the tact and experience of age. Certainly Gildas had been old enough (although, he says, not experienced enough) to write, ten years before he actually wrote; therefore he was not younger when he wrote than thirty or thirty-five. He wrote before the year 547. Finally, Gildas died about 570, and therefore was born probably not before 490 . His birth and the battle of Badon must lie approximately between the years 490 and 510.

Plummer and Mommsen agree that the battle of Badon was fought forty-three years and one month before Gildas wrote. Arthur fell in the battle of Camelon, which was probably fought less than forty-three years after the battle of Badon; therefore their renderings would fix the date of Gildas's writing probably after the date of Arthur's death, while my suggested rendering would not necessarily place the time of writing so late.

According to my rendering of the passage quoted from Gildas above, Gildas may possibly have written before the battle of Camelon: his having done so without reference to Arthur would justify the assumption that Arthur was an entirely fabulous personage. If he wrote soon after the battle of Camelon, his silence would seem to be almost equally significant.

Half a century after Geoffrey's work appeared, Giraldus Cambrensis published a tradition, which may have sprung up to account for the silence of Gildas regarding Arthur, to this effect: 'And of Gildas, who inveighs so bitterly against his own nation, the Welsh say that he wrote [the Excidium] in offence because of the death of his brother, a prince of Scotland' (i.e. of Strathclyde), 'whom King Arthur had killed. Because of this, when [Gildas] heard of his brother's death, he threw into the sea, so they assert, all the many noble books which he had written of the deeds of Arthur, and of his nation's praises ; and for this reason nothing is found related in authentic writings concerning so great a prince.' 
Geoffrey of Monmouth's contemporary and continuator, Caradoc of Llancarvan, in his Life of Gildas, says that Gildas was one of the sons of $\mathrm{Caw},{ }^{1}$ ' the most noble of the northern kings of Scotland.' Gildas's twenty-three brothers fought against Arthur, whom Gildas loved. The eldest, Hoel, a great warrior, 'obeyed no king, not even Arthur'; and he often led invasions from Scotland. Arthur overthrew the brothers, and killed Hoel in the Isle of Man (Minau). Gildas was teaching and preaching in Armagh; he grieved over the death of his brother, but passing through Britain on his way to Rome he gave Arthur the kiss of peace, and Arthur did penance and made amends.

But the Rhuys Life says that Gildas communicated with Bridget, and was invited to Ireland by King Ainmire. Bridget died in 524, or a few years earlier, according to Irish and Welsh annals ; but Ainmire (Setna's son, Columba's cousin, who had been on the winning side in the battle of Cuil-dremne) reigned from 566 to 569 , and died the year before Gildas's death, according to the Annals of Ulster. Ainmire is first mentioned there in 543. Gildas's voyage to Ireland, placed in [565] by MS. B. of the Annales Cambrioe (Ab Ithel's edition, p. 5), was not necessarily his first visit. Since Arthur must have been dead many years before 565, if there is any truth in Caradoc's statement it would seem to point to an earlier visit of Gildas to Ireland.

The Rhuys Life says that Gildas was thirty years old when he settled in Brittany, after returning from his journey to Rome. This is quite unauthoritative, but, if correct, would place his return from Ireland approximately before 530 ; and it would allow ten years to have passed between the death of his brother and the writing of the epistle, which might yet have been written before Arthur's death.

1 Spelt Nau; Caunus, king of Arecluta, i.e. of Strathclyde, according to the Rhuys Life. But Anscombe says that Gildas's name 'does not occur in any list of the children of Caw' (Archiv für celtische Lexicographie, ii. 184). 
Gildas implies that the kings whom he scourges with his epistle had not been among the first to succeed against the Saxons; not remembering the straits to which their predecessors had been driven, they were becoming degenerate in prosperity, and instead of preparing for future dangers they were wasting their strength in dissension and crime. Gildas's purpose is to warn them that, unless they mend their ways, God's vengeance will recall their enemies to conquer them.

Gildas certainly implies that he had also some definite cause for writing the Excidium, when he says that he had put off writing for more than ten years. But if he had had some special cause of offence against Arthur, and if Arthur had been still alive, he would surely not have omitted Arthur from his list of tyrannous kings.

Gildas directs his invective against five kings :

I. Constantinus, king of Devon and Cornwall, inmundae leaenae Damnoniae tyrannicus catulus. (If this Constantine was the king of Cornwall who entered monastic life about 598 , he would seem to have lived for some time later still. When Gildas wrote, Constantine was already old enough to have repudiated his wife. Four of the five kings had done so. Geoffrey of Monmouth says that this Constantine was Arthur's 'relative, the son of Cador, Duke of Cornwall'; the Aberdeen Breviary (unauthoritative) says that St. Constantine was the 'son of Paternus, King of Cornwall,' and that he died about 576.)

II. Aurelius Caninus, catule leonine; the last survivor of his family, relictus . . jam solus ac si arbor in medio campo arescens. (Zimmer, in Nennius Vindicatus, 307, would place the kingdom of Aurelius between Devon and South Wales, perhaps with its capital at Caerleon-on-Usk. But this location depends entirely upon the order in which Gildas names the kings. There is only general likelihood that he has followed correct geographical order.)

III. Vortiporus, King of South Wales (Demetarum, Pembrokeshire, according to Zimmer); pardo similis 
moribus et nequitiis discolor. He was an old man, canescente jam capite; the wicked son of a good king.

IV. Cuneglasus : urse, multorum sessor, aurigaque currus receptaculi Ursi, . . . Cuneglase, Romana lingua lanio fulve. (His kingdom Zimmer would place between South Wales and Anglesey. This location is based upon the order in which the kings are named, and also upon the Annales Cambriae's genealogies, which he quotes thus from Harleian MS. 3859, comparing Y Cymmrodor, ix. 170, 172 : Mailcun map Catgolaun lauhir map Eniaun girt map Cuneda, and Cinglas map Eugein dantguin map Enniaun girt map Cuneda. These pedigrees, if correct, would show that Maglocunus (Mailcun) and Cuneglasus (Cinglas) were cousins. Zimmer argues that Cuneglasus must have reigned in the land of North Wales, later ruled by the descendants of Cuneda, i.e. between the Teifi and the Dee. This conjecture does not wholly agree with what Gildas says of Maglocunus's kingdom.)

V. Maglocunus, king in an island (almost certainly Anglesey); insularis draco, loftier than almost all the leaders of Britain both in stature and in kingdom (cunctis paene Britanniae ducibus tam regno . . . quam status liniamento editiorem.) (His kingdom must therefore have extended far beyond Anglesey. He was probably king in North Wales, as he is called in the Historia Brittonum (ch. 1xii.) and the Annales Cambriae. From Gildas's account Maglocunus appears to have deposed his uncle, and afterwards to have retired to a monastery for a time. This uncle may have been the father of Cinglas. Maglocunus died in 547.)

Zimmer argues that all the kings named ruled in the country extending from Devon to Anglesey, while the country to the north, from Chester and Leeds to Glasgow, including Lancashire, Westmoreland, Cumberland; the West Riding of Yorkshire; and southern Scotland, from the Irish Sea to the North Sea-perhaps he means at Dunbar-was an independent British kingdom (Cumbria). This last kingdom, he says, is the only region of Welsh Britain 
where copies of Gildas's work are known to have been preserved. (Nennius Vindicatus, 308, note.) Therefore, he concludes, none of the kings concerned reigned in that district.

But if a sixth king reigned in Cumbria, he is not excluded from the general condemnation of the kings of Britain; we cannot assume that Cumbria was not included in Gildas's use of the word Britannia. And unless a degenerate son or grandson of Ambrose is implied to have been king in another province, Gildas might be understood to mean that these five kingdoms included the whole of Roman Britain which had not been occupied by the Saxons. Notwithstanding Zimmer's ingenious reasoning, we do not know the position of the kingdoms of Cuneglasus and Aurelius Caninus.

We have now to consider the epithets which Gildas uses in addressing these kings: (I.) 'tyrannical cub of the foul lioness of Damnonia '; (II.) 'lion's cub,' from Jeremiah, li. 38 (the metaphor is a compliment to his courage); (III.) 'like a pard, parti-coloured in customs and wickednesses'; (cf. Jeremiah xiii. 23) ; (IV.) ' a bear' ; (V.) 'island dragon.' These are all obvious enough metaphors. But in the case of Cuneglasus (IV.) he adds a very odd expression, the meaning of which is not so obvious. The apostrophe runs thus : 'Thou bear, thou rider of many, and charioteer of the car, the shelter of the bear; ... Cuneglasus, in the Roman tongue " yellow-haired butcher." ,

The words receptaculum ursi mean a bear's refuge or lurking-place, or the place where a bear was kept. Receptaculum came to mean a keep or fortress; but there is no such name as Cair-arth in the list of British cities placed after the Historia Brittonum. And it is altogether improbable that the words are to be taken literally.

Taken allegorically, 'the car which protects the bear,' or 'the car which holds the bear,' must surely mean the constellation of the Great Bear (Arctos), which was also anciently called the Waggon. (Part of this constellation, 
the Plough, has also been called Charles's Wain and Arthur's Wain.) By the expression 'the driver of the Waggon, which protects (or holds) the Bear,' nothing could have been meant but Boötes, the Waggoner, the constellation which follows the Great Bear. ${ }^{1}$

But if this is his meaning, Gildas has changed the Waggon to a chariot, and has altered the gender of the Bear; it is feminine in Greek and Latin legend. Both changes are such as would make the allegory applicable to a warrior king. ${ }^{2}$

No other possible explanation of these words of Gildas has occurred to me. And considering that the words were written by Gildas, a florid stylist, ${ }^{3}$ this explanation is not absurdly far-fetched, provided that the metaphor is a play upon the name of the king, with allegorical meaning.

Gildas explains the name Cuneglasus in the sense of 'yellow-haired butcher'; and although this is not a very correct translation of the word, at least it shows that the metaphor has nothing to do with the name Cuneglasus. Also the name Boötes resembles no known British name of Gildas's time.

But in the Middle Ages Boötes was very often called by another name, Arcturus (the bear-ward); and this name has a close resemblance to the name Arturus or Arthur. ${ }^{4}$

1 Aratos, Phainomena, pp. 91-93. 'Behind Helike' (the Great Bear) 'is borne

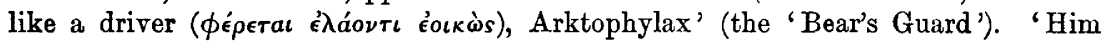
men call Boötes, because he seems to touch the Waggon of the Bear.'

2 Perhaps Gildas thought of the Bear as being baited by the Hunting Dogs; in that case the change of gender was natural, and necessary to the dignity of the metaphor. A somewhat similar metaphor occurs in Shakespeare in the words 'despite the bear-ward that protects the bear' in Henry VI., Part II. Act v. Scene 1. Here the bear-ward is an earl and the (baited) bear his crest (the 'bear and ragged staff').

The word 'bear' when used in the sense of 'fierce warrior' was masculine in Latin (ursus).

3 As an example of Gildas's style one may recollect that he calls a Scottish firth the 'valley of Tethys' (Tithicam vallem); Tethys, the wife of Oceanus, meaning metonymically the sea.

4 In a late Middle-Irish tract on the Constellations, Revue Celtique, xxx. 404, the constellation is still called 'Arcturus,' with the note ' which had the name Boötes.' The name Arcturus was originally, and is now, restricted to the brightest star in the constellation.

The change from Arturus to Arcturus is no greater than that from Cinanus, 
Therefore my interpretation of Gildas's words, if it is correct, would lead to the conclusion that the king's name was Arturus Cuneglasus. Can we prove that this was not the Arthur of legend ?

Here is what Gildas says of Cuneglasus: 'Why dost thou also wallow in the ancient filth of thy wickedness, [revived ?] from the years of thy youth $;^{1}$ thou bear, thou rider of many, and charioteer of the car which holds the bear; despiser of God, debaser of his order ; ${ }^{2}$ Cuneglasus, in the Roman tongue lanio fulve' (yellow-haired butcher): ' why makest thou so great a struggle against both God and men? Against men, namely thy fellow-citizens, with definite acts of violence (armis specialibus); against God with unlimited crimes (infinitis sceleribus)? Why, besides innumerable lapses, after repudiating thy own wife, dost thou receive her villanous sister, who had vowed herself to the perpetual chastity of widowhood to God,-as the poet says, to the highest sensitiveness to the gods (teneritudinem caelicolarum), with the undivided reverence of her mind, or rather with insensibility to earthly influences' (hebetudine nympharum; the translation is conjectural), 'contrary to the forbidding of the apostle, who denies that adulterers can be citizens of the heavenly kingdom? Why dost thou provoke with frequent wrongs the groans and sighs of the saints who wrestle for thee in the body, instead of [injuring] the teeth (vice... dentium) of the foul lioness who will one day break thy bones? Desist, I pray thee, as the prophet says' (Psalm xxxvii.-in Vulgate, xxxvi. 8), 'from wrath, and abandon the fatal and selfdestructive rage which thou dost entertain against heaven

\footnotetext{
'Cynan' or 'Conan,' to Caninus, 'canine'; if, as seems probable, Gildas has made this change in the name Aurelius Caninus. It is immaterial that Arturus would have been here probably in the vocative case, Arture. The difference appears still less significant when we remember that Arct- of Arcturus is the parallel of Welsh arth, a bear; and that 'A ккrovpos, if borrowed by the Britons, would have taken the form Arthur in Welsh.

${ }^{1}$ I take this to refer to the acts of violence spoken of below.

2 This evidently refers to Cuneglasus' second marriage.
} 
and earth, that is, against God and his flock. Rather change thy customs, and make those pray for thee who have the power to bind above the sinners whom they have bound upon earth, and to release above the penitent whom they have absolved' (St. Matthew xvi. 19). ${ }^{1}$ 'Cherish not, as the Apostle says, wisdom in pride, nor hope based upon the uncertainties of wealth; but [cherish] hope in God, who gives thee many things abundantly; so that by mending thy ways, thou mayest lay up for thyself as a treasure a good foundation for the future, and mayest have true life' (cf. 1 Timothy vi. 17-19), 'eternal, not ephemeral; otherwise thou shalt know and see, even in this world, how bad and bitter it is that thou hast forsaken the Lord thy God, and hast not fear of him before thee' (Jeremiah, ii. 19); ' and that in the future thou art burned in a noisome mass of eternal flames, yet without any manner of death, for the souls of the wicked are as immortal in eternal flame as are the souls of the holy in bliss.'

The 'foul lioness' must have been the 'foul lioness of Damnonia,' the mother of Constantine. Had Cuneglasus offended her by repudiating his wife? Gildas seems here to take Cuneglasus' side; and he does not blame him for the repudiation. It is remarkable that, according to Geoffrey (ix. 9), Arthur's wife, Guinevere, was the fosterchild of Constantine's father.

There is nothing in Gildas's account of Cuneglasus which clashes with the account of Arthur given in the Historia Brittonum, and only one essential point of difference from the account of Arthur in Geoffrey's History:-Geoffrey implies that Arthur died very soon after the repudiation of his wife, and mentions no second marriage. The idealization of Arthur's character which begins in Geoffrey is no bar to identification. The only crucial difference is between the pedigree of Cinglas given in the Annales Cambrioe's genealogy, and the descent given to Arthur by Geoffrey;

1 This quotation from St. Matthew is one of the points of resemblance between Gildas's epistle and Patrick's letter to the subjects of Coroticus.

VOL. VIII.

L 
and neither Geoffrey nor the genealogy has unimpeachable authority.

According to the genealogies which follow the Annales Cambriae, Cinglas and Mailcun were great-grandsons of Cuneda, whose descent by eighteen generations is traced from Beli the Great, and Anna, the cousin of the Virgin Mary. In the Historia Brittonum (ch. Ixii.), Cuneda is said to have been Mailcun's great-great-great-grandfather (atavus), and to have gone to North Wales from Manau on the Forth, one hundred and forty-six years before Mailcun's accession. This statement tends to discredit the genealogy, which seems to have missed two generations. The genealogy was written some two hundred and seventyfive years later than the earliest part of the Historia Brittonum; to which part, however, chapter sixty-two may not belong.

Geoffrey of Monmouth's History is so full of fable that it is very difficult to detect any germs of historical truth which it may contain. Stories about Arthur had sprung up long before Geoffrey's day; but they, and he, and his followers, belong to literature, not to history. Nevertheless one might expect that relationships would be the details most correctly given.

Geoffrey says that Arthur's father, Uther Pendragon, was the brother of Aurelius Ambrosius. Thus the pedigree of Ambrose became the pedigree of Arthur. But neither Uther nor his son occurs in the old Welsh genealogies indexed by Mr. Anscombe, except in the Mostyn MS. of Geoffrey's History. There are later pedigrees of Arthur's nephew Geraint. (See Anscombe, in the Archiv für celtische Lexicographie, ii. 157-158.)

The relationship between Arthur and Ambrose is under suspicion also because Geoffrey would not have been willing to admit that he did not know Arthur's descent, ${ }^{1}$ and

1 Similarly in the case of Ambrose we have no account of his descent earlier than Geoffrey's. Gildas says simply that Ambrose's parents were Romans of high rank (parentibus, purpura nimirum indutis); the earliest part of the Historia Brittonum says that Ambrose's father was a Roman consul. 
because it must have been Geoffrey's wish to connect Arthur with the most illustrious man of the previous generation. Against the relationship is to be placed the silence of the Historia Brittonum.

Further, the story of Arthur's birth given by Geoffrey reads like an attempt to unify different accounts of his parentage.

Annotators, apparently of the thirteenth century, have inserted in Nennius (Mommsen's edition, 199; Petrie's, 73) : 'And [Arthur] was the conqueror in all the [twelve] battles. Mab uter in British is filius horribilis in Latin, because he was cruel from his childhood. Artur translated into Latin is ursus horribilis' (terrible bear), 'or malleus ferreus' (iron hammer) 'wherewith are broken the lions' teeth (mole leonum).' All three etymologies remind one of Gildas's words about Cuneglasus : did the annotators understand those words to refer to Arthur?

By his translation of mab uter as the 'terrible youth,' the annotator seems to reject Geoffrey's statement that Arthur was the son of Uther. And Arthur himself might have been called Pendragon; according to Geoffrey, Arthur wore a dragon-shaped helmet (ix. 4). It is more likely that Uther was an epithet ${ }^{1}$ of Arthur's father. The words mab uter were perhaps a traditional appellation of Arthur, and cannot be dismissed as the invention of the legend-makers. It is not likely that Uther was an additional epithet of Eugein Dant-guin ('Ewen White-toothed,') the father of Cinglas in the genealogy; so that if the genealogy and Geoffrey are both right in these particulars, Cinglas and Arthur were probably not the same. But both authorities have been impugned. And, of course,

\footnotetext{
1 Uther seems not to occur as the name of any one else. Holder does not include it as a proper name in his Sprachschatz. Jago quotes it from Borlase as a Cornish word, uter (beside the more usual uthec) meaning horrible; Williams, under uthec, quotes Welsh uthyr ; and Stokes and Holder quote from Ernault the Welsh form as ' $u t h r$, awful.' The Cornish word $u t h$, horror, is certainly a Brythonic parallel of the Gaelic fuath.
} 
neither authority could stand for a moment if it were in conflict with Gildas. ${ }^{1}$

Ambrose was descended from the Romans, and he probably ruled over a province of Roman Britons in Britain : according to the Lives of Gildas, Caw would appear to have been king at the same time of the Roman Britons of part, at least, of Cumbria. The Irish Nennius (probably misunderstanding the Historia Brittonum) says that Ambrose was 'king of the Franks and the Armorican Britons'; but according to Geoffrey, he was king of Britain, while his father's brother, Aldroen, was king of Brittany, the fourth from Conan, whom Maximus had placed there. Localities in the legends are so incorrectly given that no trust can be placed in them.

There is some likelihood that Arthur belonged to the province of Ambrose. Arthur's alleged killing of Gildas's brother may have been an incident in his usurpation of the kingdom of Cumbria, or a part of it. This is very dubious ; but some traditions and some of the place-names of his battles appear to connect Arthur with the south of Scotland.

In Geoffrey's story Ambrose was succeeded as king of Britain by Uther, and Uther by Arthur, so that the whole of Uther's short reign and almost the whole of Ambrose's reign intervened between Ambrose's success over Hengist and the exploits of Arthur. According to Geoffrey, Arthur died in 542, in the battle of the Cambula (the battle of Camelon), where he fought against Modred, the son of his sister Anna and Lot, consul of Lothian. ${ }^{2}$

In the Annales Cambriae the battles of Badon and

1 The statement that Gildas laments ignorance of his subject is incorrect; he deplores conventionally his inexperience [in writing] (imperitiam). In this he had the precedent of his countryman, Fastidius.

2 The anonymous Life of Kentigern (later than Geoffrey) calls this Lot 'Leudonus,' and says that he was by one marriage the father of Thenew or Thanea, the mother of Kentigern. But it says also that Kentigern's father was the famous Owen who, with his father Urien, fought against the Angles of Northumbria, c. 570; an impossible relationship, because Kentigern was very old when he died, and his death is recorded in 612 by the Annales Cambriae. The Life has perhaps been misled by Geoffrey, who makes Urien (Urianus) the brother of Lot. 
Camelon are entered under the years 516 and 537 respectively ; but the first date is wrong, and the second is under suspicion. Since Gildas was born in the year of Arthur's final great victory, he must have been a generation younger than Arthur. And Gildas died in 570. Therefore the date 537 is not an impossible one for Arthur's death, especially if Arthur was young when he began his career of war. Geoffrey of Monmouth says that Arthur was fifteen years old when he became king.

In Geoffrey's account Arthur was succeeded by Constantine, after whom reigned in succession Aurelius Conanus, Wortiporius, Malgo, Careticus. ${ }^{1}$ Some words used in speaking of Careticus seem to show that his name is a mistake for Cuneglasus. Geoffrey shows here very clearly the artificial nature of his historical method, when he turns Gildas's five provincial kings into five successive kings of all Britain.

The scheme of my argument is this: (1) Arthur may have been alive when Gildas wrote ; (2) one of the kings addressed by Gildas appears to have borne the name Arturus ; (3) this king's wife and Arthur's wife may have been the same; (4) annotators of Nennius seem to have regarded the two kings as the same.

I conclude this series of possibilities with an hypothesis. If Gildas had called Cuneglasus explicitly by the name Arturus, this might conceivably have been another Arthur : but if the stellar metaphor stands for that name at all, it can have meant no other Arthur than Arthur, the king of romance.

1 Geoffrey's History, xi. 8: 'To Malgo succeeded Careticus, a lover of civil wars, and hateful to God and to the Britons.' These words seem to have been derived from Gildas's account of Cuneglasus. 